\title{
INISIASI STRATEGI MANAJEMEN LEMBAGA PENDIDIKAN ISLAM DALAM MENINGKATKAN MUTU SUMBER DAYA MANUSIA ISLAMI DI INDONESIA DALAM MENGHADAPI ERA GLOBALISASI
}

\author{
M. Ihsan Dacholfany \\ Fakultas Agama Islam \\ Universitas Muhammadiyah Metro \\ E-mail: mihsandacholfany@yahoo.com
}

\begin{abstract}
Islamic educational institutions are expected to produce human resources who is faithful and devoted to have insight into the science and technology. To achieve these expectations, of course Islamic educational institutions should revitalize the role of educational institutions to be able to play an optimal role in realizingacademic excellence for education, for industrial relevance, for contribution for new knowledge, and for empowerment.Recognizing the importance of the process of improving the quality of human resources, government, managers of educational institutions, educators and learners strive to accomplish the purpose, vision and mission through a variety of activities to build better quality education through the development and improvement of curriculum and evaluation system, improvement of facilities education, development and procurement of teaching materials, and training for teachers and education personnel.
\end{abstract}

Keywords: Initiation, strategy management, human resources

\section{PENDAHULUAN}

Perkembangan lembaga pendidikan Islam dewasa ini telah menimbulkan keprihatinan meluas di tengah masyarakat, terlebih dihadapkan pada krisis multidimensional yang berkepanjangan dan masyarakat pun mengharapkan kepastian bagaimana bangsa ini akan menghadapi kompetisi dengan bangsa lain dalam menghadapi globalisasi.

Lembaga pendidikan Islam diharapkan dapat membina dan menghasilkan sumber daya manusia Islami sehingga menghasilkan alumni yang bermutu dengan memiliki wawasan ilmu pengetahuan, skill dan teknologi dan punya bekal iman takwa sehingga dapat menguasai, mengembangkan dan mengaplikasikan dengan tetap dilandasi nilai-nilai agama, moral, dan akhlak mulia sesuai dengan norma aturan agama maupun pemerintah.

Peranan lembaga pendidikan Islam di Indonesia dalam mempersiapkan sumber daya manusia yang profesional dan memiliki kompetensi sangatlah penting, pada umumnya lembaga pendidikan Islam di negara Indonesia masih mengalami ketertinggalan dibanding negara lain, bahkan terasing dari keperluan dan realitas sosial, ekonomi, pendidikan, serta budaya masyarakatnya. Lembaga pendidikan Islam memerlukan otonomi dan independensi untuk dapat 
memperbaiki dan memperkuat perannya itu sebagai salah satu tonggak kemajuan dan perkembangan suatu bangsa.

Untuk melakukan perubahan fundamental agar dapat menghasilkan sumber daya manusia Islami yang bermutu maka lembaga pendidikan seyogyanya merevitalisasi peran lembaga pendidikan supaya mampu berperan secara optimal dalam mewujudkan academic excellence for education, for industrial relevance, for contribution for new knowledge, dan for empowerment.

Inisiasi Strategi Manjemen dalam meningkatkan sumber daya manusia perlu direncanakan dan diatur dengan baik serta sudah merupakan bagian dari sunnatullah, yaitu dengan melihat bagaimana Allah SWT menciptakan alam semesta dengan hak dan perencanaan yang matang disertai dengan tujuan yang jelas. Sebagaimana firman-Nya :

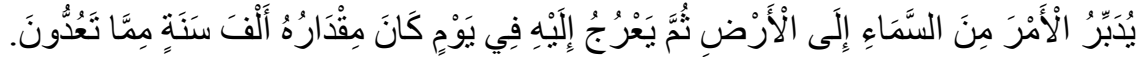 Artinya; Dia (Allah) mengatur urusan dari langit ke bumi, kemudian (urusan) itu naik kepada-Nya dalam satu hari yang kadarnya adalah seribu tahun menurut perhitunganmu (as-Sajadah, ayat: 5)

Demikian juga dalam kajian lembaga pendidikan, masalah sumber daya manusia yang menjadi hal yang krusial dalam meningkatkan daya saing lulusan. Mutu tenaga pendidik dan kependidikan menjadi hal yang utama untuk meningkatkan daya saing lulusan lembaga pendidikan, jadi tingginya mutu sumber daya manusia Islami lembaga pendidikan maka akan tinggi juga daya saing di lembaga pendidikan tersebut karena sumber daya manusia akan menciptakan lulusan-lulusan yang kompetitif dibandingkan lulusan-lulusan di lembaga pendidikan lainnya.

Melihat betapa pentingnya manejemen peningkatan mutu lulusan lembaga pendidikan, agar dapat dalam mengimplementasikannya tujuan ideal sebuah lembaga lembaga pendidikan dapat tercapai dan memuaskan masyarakat, stakeholder dan orang tua. Dengan ini penulis menyimpulkan beberapa permasalahannya:

1. Apa tantangan yang menjadi faktor penghambat dalam proses peningkatan mutu sumber daya manusia di lembaga pendidikan di Indonesia?.

2. Apa solusi dalam menyelesaikan tantangan dalam proses peningkatan mutu sumber daya manusia di lembaga pendidikan di Indonesia?.

3. Bagaimanakah Strategi dan Tekhnik manajemen yang dilakukan oleh Lembaga pendidikan dalam meningkatkan mutu sumber daya manusia?.

4. Apakah Faktor yang Mempengaruhi dalam Peningkatan Mutu sumber daya manusia?. 


\section{KAJIAN TEORI Inisiasi}

Secara istilah, seperti yang ditulis oleh Henrik Bognan dalam Western Esotericism and Rituals of Initiation menjelaskan, inisiasi berasal dari bahasa Latin, initiare, yang berarti "memulai". Ada juga yang mengartikan bahwa asal katanya dari inisiate (bahasa Inggris), yang berarti mengawali, memulai ke sesuatu yang baru ${ }^{1}$.

Inisiasi berasal dari kata bahasa Latin, initium, yang berarti masuk atau permulaan, secara harafiah berarti masuk ke dalam². Dapat juga diartikan bahwa inisiasi adalah permulaan suatu kehidupan baru dalam tatanan hidup baru. Inisiasi sebenarnya hanyalah istilah berguna dalam pembukaan jiwa. Dapat dilihat, banyak orang disibukkan oleh begitu banyak jenis hambatan, baik terlihat maupun tidak, jadi yang disebut inisiasi adalah proses untuk membuka gerbang kebijaksanaan dan membiarkannya mengalir melalui dunia ini.

Dalam makalah ini penulis mendiskripsikan bahwa inisiasi strategi manajemen lembaga pendidikan dalam meningkatkan mutu sumber daya manusia islami sehingga mampu berdaya saing dengan negara lain sangatlah menarik untuk dikaji dan diteliti.

\section{Strategi.}

Pada dasarnya, istilah strategi dapat dirumuskan sebagai suatu tindakan penyesuaian untuk mengadakan reaksi terhadap situasi lingkungan tertentu (baru dan khas) yang dapat dianggap penting, di mana tindakan penyesuaian tersebut dilakukan secara sadar berdasarkan pertimbangan yang wajar ${ }^{3}$

Menurut Gaffar memberi pengertian bahwa strategi adalah rencana yang mengandung cara komprehensif dan integratif yang dapat dijadikan pegangan untuk bekerja, berjuang dan berbuat guna memenangkan kompetisi. Strategi juga merupakan instrumen manajemen yang ampuh dan tidak dapat dihindari, tidak hanya untuk survival dan memenangkan persaingan, namun juga untuk tumbuh dan berkembang ${ }^{4}$. Sedangkan Syaiful Sagala mengatakan bahwa strategi merupakan rencana yang komprehensif mengintegrasikan segala resources dan capabilities yang mempunyai tujuan jangka panjang untuk memenangkan kompetisi ${ }^{5}$. Martin mengemukakan bahwa strategi diartikan sebagai rencana yang disatukan, menyeluruh dan terpadu. Tiga komponen tersebut berkaitan dengan keunggulan strategi perusahaan yang dirancang untuk memastikan bahwa tujuan utama dari perencanaan dapat dicapai melalui pelaksanaan yang tepat oleh

\footnotetext{
${ }^{1}$ Henrik Bognan, Western Esotericism and Rituals of Initiation, 2007, p.23

${ }^{2}$ C.Groenen, Teologi Sakramen Inisiasi Baptisan Krisma: Sejarah dan Sistematika, Jogjakarta, Kanisiu, 1992, h.8

${ }^{3}$ Mastuki HS. Dkk, Managemen Pondok Pesantren, Jakarta: Diva Pustaka, 2003, h. 62

${ }^{4}$ M. F. Gaffar, Membangun Kembali Pendidikan Nasional dengan Fokus: Pembaharuan Manajemen Perguruan Tinggi pada Era Globalisasi, Makalah Konvensi Nasional Pendidikan Indonesia V, Surabaya, 2004, h. 14

${ }^{5}$ Syaiful Sagala, Manajemen Strategik dalam Peningkatan Mutu Pendidikan, Bandung: Alfabeta, 2007, h.137.
} 
perusahaan. Disatukan artinya bahwa strategi mengikat semua aspek penting dan menyeluruh, artinya bahwa strategi meliputi semua aspek penting dan terpadu. Strategi diartikan sebagai suatu rencana yang serasi dan saling berkesesuaian antara satu dengan yang lainnya. ${ }^{6}$ Penulis menyimpulkan bahwa strategi adalah suatu cara yang dilakukan dengan teratur dan terprogram untuk mencapai tujuan dan harapan yang diinginkan.

\section{Pemimpin dan Manajemen.}

Miftah Thoha mengemukakan bahwa suatu organisasi akan berhasil atau gagal sebagian dapat ditentukan oleh kepemimpinan. Pengertian tersebut menjelaskan bahwa keberhasilan organisasi dalam menjalankan programnya didukung oleh kepemimpinan yang baik pula, oleh karena itu, kepemimpinan yang baik harus mampu dipahami dan diterapkan secara baik dalam diri pemimpin? ${ }^{7}$.

Menurut Imam dalam bukunya yang berjudul Kepemimpinan dan Keorganisasian, ada beberapa peran dalam kepemimpinan, yaitu: mempengaruhi orang lain (karyawan/kelompok), Mengarahkan, memotivasi dan mengkoordinir tingkah laku orang lain (karyawan) atau kelompok, melakukan kerja sama untuk mencapai tujuan yang diinginkan (konsep relasi/relation concept), Sebagai penggugah semangat dan memberi inspirasi karyawan ${ }^{8}$. Menurut George R.Terry, fungsi manajmen berfungsi sebagai planning (perncanaan), organizing, actuating (menggerakkan). Controlling ${ }^{9}$, sedangkan menurut Lutter Gulick yang di kutip oleh Suharsini Arikunto, fungsi manajemen adalah planning (perencanaan), dan organizing (pengorganisasian) serta staffing (kepegawaian), directing

(pengelolaan), coordinating (koordinasi), reporting (pelaporan) serta terakhir adalah budgetting (rencana biaya) ${ }^{10}$.

\section{Peningkatan Mutu}

Dalam bidang pendidikan menejemen peningkatan mutu dapat didefinisikan sebagai sekumpulan prinsip dan tehnik yang menekankan pada peningkatan mutu dengan bertumpu pada lembaga pendidikan untuk secara terus menerus dan berkesinabungan meningkatkan kapasitas dan kemampuan lembaganya untuk memenuhi tuntuan kebutuhan peserta didik dan masyarakat serta mampu bersaing di tengah-tengah kemajuan globalisasi dengan mampu bertahan akan memproduk peserta didik berkualitas dan terpenuhinya kepuasan

\footnotetext{
${ }^{6}$ Martin Amnillah, Implentasi Perencanaan Strategi Pendidikan Dasar Tahun 2001-2003 Dinas Pendidikan Kabupaten Temanggung: Studi Kasus di SLTP Islam Nadirejo, Tesis, ,Yogyakarta: PPs. Universitas Negeri Yogyakarta, 2004.

${ }^{7}$ Miftah Thoha, Perilaku Organisasi Konsep Dasar dan Aplikasinya, Jakarta. CV. Rajawali, 1983, h. 1

${ }^{8}$ Imam Mujiono, Kepemimpinan dan Keorganisasian, UII Press. Yogyakarta, 2002, h.134

${ }^{9}$ George R. Terry: Pengertian manajemen menurut George R. Terry bahwa dalam bukunya The Principles of Managemen, 1996. p.13

${ }^{10}$ Suharsini Arikunto, Manajemen, 1993, h.38
} 
user atau stake holder. Secara bahasa, peningkatan mutu terdiri dari dua kata yaitu peningkatan dan mutu. Kata peningkatan memiliki arti proses, cara, atau perbuatan meningkatkan (usaha, kegiatan, dan lain-lain) ${ }^{11 .}$ Sedangkan kata mutu artinya kualitas atau (ukuran) baik buruk suatu benda, kadar, taraf/derajat (kepandaian, kecerdasan, dan sebagainya) ${ }^{12}$.

Departemen tenaga kerja Indonesia mengistilahkan peningkatan mutu sebagai salah satu prasyarat bagi suatu lembaga pendidikan agar dapat memasuki era globalisasi yang penuh dengan persaingan. Keberadaan madrasah sebagai lembaga pendidikan Islam tidak terkecuali. Menurutnya, yang lebih penting dalam upaya peningkatan mutu adalah ilmu perilaku manusia (Make People Before Make Product), karena pada intinya, meningkatkan mutu sama artinya dengan membangun manusia seutuhnya ${ }^{13}$.

Konsep peningkatan mutu dalam pendidikan dikelola melalui proses manajemen peningkatan mutu berbasis sekolah (MPMBS) yang merupakan embrio dari manajemen berbasis sekolah (MBS). Dalam MPMBS, konsep peningkatan mutu sekolah selayaknya diprogram dan direncanakan serta dilakukan sendiri secara mandiri oleh sekolah berdasarkan kebutuhan sekolah itu sendiri untuk mencapai keberhasilan.

Peningkatan mutu pada semua jenis dan jenjang pendidikan (dasar, menengah, dan tinggi), pada dasarnya dipusatkan pada tiga faktor utama, yaitu:

a. Kecukupan sumber-sumber pendidikan untuk menunjang proses pendidikan dalam arti kecukupan adalah penyediaan jumlah dan mutu guru serta tenaga kependidikan lainnya; buku teks bagi murid dan perpustakaan; dan sarana serta prasarana belajar.

b. Mutu proses pendidikan itu sendiri, maksudnya adalah kurikulum dan pelaksanaan pengajaran untuk mendorong para siswa belajar lebih efektif.

c. Mutu output dari proses pendidikan, dalam arti keterampilan dan pengetahuan yang telah diperoleh para siswa ${ }^{14}$.

Dalam hal mutu lulusan menjadi permasalahan yang utama menyangkut dengan daya saing lulusan. Mutu lulusan itu juga boleh jadi dikarenakan mutu tenaga pendidik, sarana dan prasarana pendidikan, dan juga kebijakan lembaga pendidikan tersebut. Hal tersebut yang menjadi penyebab krusial untuk memajukan dan meningkatkan mutu lulusan di lembaga pendidikan. Mutu lulusan akan meningkatkan daya saing dari lulusan itu pribadi dan lembaga pendidikan yang bersangkutan. Perguruan tinggi pada barisan lembaga pendidikan-lembaga pendidikan terbaik memerlukan perubahan yang

${ }^{11}$ Tim Penyusun Kamus Pusat Pembinaan dan Pengembangan Bahasa, Kamus Besar Bahasa Indonesia, Jakarta: Balai Pustaka, 1989, h. 951

${ }^{12}$ Ibid., h. 604.

${ }^{13}$ Depnaker, Peningkatan Mutu Terpadu, 1986, h. 2.

${ }^{14}$ Visi dan Strategi Pembangunan Pendidikan untuk Tahun 2020 Tuntutan Terhadap Kualitas Depdikbud, 1996; Ceramah Menteri Pendidikan dan Kebudayaan pada Konvensi Nasional Pendidikan Indonesia III Ujung Pandang, 4-7 Maret 1996. 
fundamental sehingga mampu bersaing (better competitive situation). Untuk itu seyogyanya lembaga pendidikan harus memiliki strategic intent, different and distince. Untuk mewujudkannya perlu dilakukan transformasi kelembagaan yang lebih kompleks dari sekedar pengembangan organisasi (organization development). Lembaga pendidikan merupakan lembaga, dibangun komunitas akademik yang bersifat kolegial, dan menjunjung tinggi academic value untuk mencerdaskan bangsa, inilah yang membedakannya dengan organisasi lain.

\section{Sumber Daya Manusia}

Dalam sebuah organisasi, peranan sumber daya manusia sangat urgent dan penting. Peran sumber daya manusia ini akan maksimal jika dikelola dengan baik. Pimpinan lembaga pendidikan sebagai top leader dalam lembaga sekolah mempunyai peran sentral dalam pengelolaan personalia sehingga sangat penting bagi pimpinan lembaga pendidikan untuk memahami dan menerapkan pengelolaan personalia dengan baik dan benar.

Di Indonesia konsep tujuan pendidikan adalah membentuk manusia seutuhnya yang tercermin dari iman dan taqwa, berkepribadian, cerdas, sehat serta bertanggung jawab. Untuk itu, maka pendidikan dalam prakteknya perlu menerapkan asas-asas yang sesuai.

Pada dasarnya yang dimaksud sumber daya manusia adalah orang-orang yang melaksanakan suatu tugas untuk mencapai tujuan-tujuan tertentu. Dalam konteks lembaga pendidikan dibatasi dengan sebutan karyawan atau pegawai, oleh sebab itu, personel di lembaga pendidikan meliputi unsur tenaga pengajar dan tenaga kependidikan .Secara lebih terperinci dapat disebutkan keseluruhan warga sekolah, yaitu jika ditingkat sekolah ada kepala sekolah, guru, pegawai, tata usaha, dan pesuruh atau penjaga sekolah, adapun di tingkat perguruan tinggi ada rektor atau ketua, wakil, ketua jurusan, tata usaha, karyawan, maka yang dimaksud dengan Manajemen sumber daya manusia (SDM) adalah teknik atau prosedur yang berhubungan dengan pengelolaan dan pendayagunaan personalia sekolah/madrasah (SDM), baik tenaga edukatif maupun tenaga administratif secara efektif dan efisien banyak tergantung pada kemampuan kepala sekolah/madrasah baik sebagai manager dan pemimpin pada lembaga pendidikan tersebut ${ }^{16}$.

Menurut Soekidjo Notoatmodjo mengatakan bahwa tujuan utama manajemen sumber daya manusia (MSDM) adalah untuk meningkatkan kontribusi sumber daya manusia (karyawan) terhadap organisasi dalam rangka mencapai produktivitas organisasi yang bersangkutan. Hal ini dapat dipahami bahwa semua kegiatan organisasi dalam mencapai misi dan tujuannya tergantung kepada manusia yang mengelola organisasi itu, oleh sebab itu, sumber daya

\footnotetext{
${ }^{15}$ M. Ihsan Dacholfany, Peranan Pengambilan Keputusan Dalam Rangka menciptakan inovasi Di bidang pendidikan, Jurnal Dewantara Vol I , No .0 1 Januar i-Juni 2016, h.25

${ }^{16}$ Baharuddin dan Moh. Makin, Manajemen Pendidikan Islam, Malang, UIN-Maliki Press, 2010, h. 61
} 
tersebut harus dikelola sedemikian rupa sehingga berdaya guna dan berhasil guna dalam mencapai misi dan tujuan organisasi ${ }^{17}$. Penulis menyimpulkan bahwa tujuan utama dari manajemen sumber daya manusia adalah suatu rencana yang telah diorganisir dalam usaha melaksanakan suatu aktifitas atau kegiatan yang terkontrol dengan baik dengan cara melakukan evaluasi sehingga menjadi lebih baik daripada sebelumnya.

\section{PEMBAHASAN}

\section{Faktor Penghambat Dalam Proses Peningkatan Mutu Sumber Daya Manusia Di Lembaga Pendidikan.}

Permasalahan yang utama di dalam lembaga pendidikan di Indonesia adalah masih seputar rendahnya kualitas, relevansi, efisiensi dan produktivitas serta efektivitas. Penyebabnya adalah ketersediaan pendidik dan tenaga kependidikan yang belum memadai baik secara kuantitas maupun kualitas, dan kesejahteraan pendidik yang belum memadai. ${ }^{18}$

Di antara yang menjadi faktor penghambatnya dalam proses peningkatan mutu sumber daya manusia di lembaga pendidikan antara lain adalah:.

a. Kepemimpinan dan Manajemen

Kunci kesuksesan dalam peningkatan kualitas sumber daya manusia di lembaga pendidikan sangat ditentukan oleh pemimpin dan manajerial pemimpin. Jika pemimpin tidak mampu mengatur dan tidak mempunyai keahlian dan pengalaman dalam memimpin maka akan mengalami kemunduran dan tertinggal dengan lembaga pendidikan lainnya.

b. Mutu Tenaga Pendidik

Mutu Tenaga Pendidik yang menjadi hal utama peningkatan mutu sumber daya manusia tersebut. Komitmen tenaga Pendidik dalam mengajar menjadi hal utama untuk tujuan tersebut, mengingat banyak tenaga pendidik yang tidak komitmen dalam mengajar untuk meningkatkan dan mengembangkan kualitas pembelajaran.

c. Kurangnya sarana dan prasarana

Kurangnya sarana dan prasarana pendidikan seperti perpustakaan, laboratorium, bengkel kerja (workshop), pusat sumber belajar (PSB) dan perlengkapan pembelajaran sangat menghambat tumbuhnya lembaga pendidikan yang profesional. Hal ini terutama berkaitan dengan kemampuan pemerintah untuk melengkapinya yang masih kurang. Di samping itu, walaupun pemerintah sudah melengkapi buku-buku pedoman dan buku-buku paket namun dalam pemanfaatannya masih kurang. Beberapa kasus menunjukkan banyak buku-buku paket belum didayagunakan secara optimal untuk

\footnotetext{
${ }^{17}$ Soekidjo Notoatmodjo, Pengembangan Sumber Daya Manusia, Jakarta, Rineka Cipta, 2003, h.118

${ }^{18}$ Rencana Strategis Departemen Pendidikan Nasional, 2005, h.14
} 
kepentingan pembelajaran, baik guru maupun oleh peserta didik yang berdampak pada kesiapan dalam menghadapi ujian.

d. Kompensasi

Kompensasi dapat diartikan sebagai honor atau gaji yang sesuai atau layak, sebab jika tenaga pendidik dan tenaga kependidikan tidak diberi penghargaan atau reward berupa gaji yang sesuai maka kegiatan proses belajar mengajar dan proses pelayanan pendidikan akan terkendala dan mengalami kesulitan.

e. Peningkatan Mutu

Belum ada kemauan bagi lembaga pendidikan atau pendidik sendiri bahkan peserta didik untuk berusaha meningkatkan mutu atau kualitas dari hasil pembelajaran atau pendidikan.

\section{Solusi Dalam Menyelesaikan Tantangan Dalam Proses Peningkatan Mutu Sumber Daya Manusia Di Lembaga Pendidikan antara lain adalah:}

a. Pemimpin dan Manajemen.

Pemimpin harus belajar dari pengalaman orang lain, paling tidak bertanya pemimpin sebelumnya atau berusaha untuk membaca buku bagaimana cara memimpin yang efektif selain itu harus teliti melihat preferensi orang yang akan diajak bekerjasama dalam mewujudkan tujuan, misi dan visi lembaga pendidikan tersebut. Orang yang memiliki preferensi dan kemampuan rendah dangan pemberdayaan rendah, maka ia akan bersifat complaint. Sebaliknya orang yang memiliki preferensi dan kemampuan tinggi diberdayakan maksimal maka ia akan bersifat adaftive.

b. Tenaga Pendidik dan Kependidikan

Tenaga pendidik dan kependidikan merupakan hal yang sangat urgent dalam keberlangsungan kegiatan belajar mengajar, baik di dalam kelas maupun di luar kelas, maka perlunya tenaga pendidik yang memiliki komitmen yang tinggi, contoh dalam hal mengajar, tenaga pendidik harus mempersiapkan bahan ajar dengan menggunakan metode mengajar yang sesuai dengan materi yang diajarkan, selain itu pendidik memiliki latar belakang pendidikan yang sesuai dengan bidang ilmu yang diajarkan dengan tetap berusaha memiliki wawasan keilmuan yang luas dan profesionalisme yang tinggi, kreatif, dinamis dan inovatif dalam mengembangkan ilmu pengetahuan dan memiliki kesadaran tinggi dalam bekerja yang didasari oleh niat beribadah dan selalu berupaya meningkatkan kualitas pribadi dengan menunjukan dedikasi dan disiplin tinggi serta mematuhi kode etik profesi serta bersikap dan perilaku jujur, amanah dan berakhlak mulia, sabar, ikhlas dan akomodatif dalam pergaulan serta dapat menjadi panutan bagi sesama guru, siswa dan siapa saja 
dengan berbuat secara arif dan bijak dalam menghadapi dan menyelesaikan setiap masalah

c. Kurangnya sarana dan prasarana

Lembaga pendidikan masih mengalami kekurangan sarana prasarana seperti perpustakaan, laboratorium, bengkel kerja (workshop), pusat sumber belajar (PSB) dan perlengkapan pembelajaran dapat diusahakan dari bantuan pemerintah, Komite sekolah, kerjasama orangtua dan masyarakat atau lembaga pendidikan mempunyai badan amal usaha sendiri sehingga dapat memenuhi sarana prasaran yang masih kurang dan perlu pelatihan tentang penggunaan sarana prasarana secara baik dan benar.

d. Ahmad Sanusi menjelaskan perlu adanya memorandum hukum dalam meningkatkan mutu sumber daya manusia di lembaga pendidikan. maksudnya memorandum hukum adalah pendapat hukum mengenai kasus hukum yang konkret yang membuat rekomendasi atau saran yang spesifik yang dianggap paling tepat. ${ }^{19}$

e. Belum tumbuhnya budaya mutu

Mutu atau kualitas merupakan gambaran dan karakteristik menyeluruh dari barang atau jasa yang menunjukkan kemampuannya dalam memuaskan kebutuhan yang diharapkan atau yang tersirat. Mutu dipahami pula sebagai apa yang dipahami atau dikatakan oleh konsumen. Dalam konteks pendidikan, pengertian mutu mencakup input, proses dan output pendidikan. Input pendidikan adalah segala sesuatu yang harus tersedia karena dibutuhkan untuk berlangsungnya proses. Proses pendidikan merupakan berubahnya sesuatu menjadi sesuatu yang lain, sedangkan output pendidikan merupakan kinerja sekolah, yaitu prestasi sekolah yang dihasilkan dari proses dan perilaku. Adapun budaya mutu/ kualitas, yang memiliki elemenelemen sebagai berikut: Informasi kualitas harus digunakan untuk perbaikan, kewenangan harus sebatas tanggung jawab, hasil harus diikuti hadiah dan hukuman, kolaborasi, sinergi bukan kompetisi penuh melainkan harus merupakan basis kerja sama, tenaga kependidikan harus merasa aman dalam melakukan pekerjaannya; suasana keadilan harus ditanamkan; dan imbas jasa harus sepadan dengan nilai pekerjaan. Belum tumbuhnya budaya kualitas baik dari segi input, proses maupun output pendidikan merupakan faktor penghambat tumbuhnya pimpinan lembaga pendidikan profesional. Dalam hal ini, sekolah harus selalu menggalakkan peningkatan 
mutu/kualitas, yakni kepuasan pelanggan, baik internal maupun eksternal $^{20}$.

\section{Strategi Dan Tekhnik Manajemen Yang Dilakukan Oleh Lembaga Pendidikan Dalam Meningkatkan Mutu Sumber Daya Manusia .}

Strategi dan tekhnik manajemen yang dilakukan oleh Lembaga pendidikan Islam dalam meningkatkan mutu sumber daya manusia dengan penyelarasan secara bertahap dari struktur kelembagaan (program dan sumber daya) dengan perilaku civitas akademikanya untuk mencapai kinerja yang ditargetkan (performance).

Setiap pengelola, mulai dari pengurus yayasan, pimpinan, tenaga pendidik dan tenaga kependidikan yang ada di lembaga pendidikan harus mempunyai komitmen terhadap target mutu, ketepatan waktu, dan efektivitas program. Lalu adanya pembaharuan proses kegaiatan belajar mengajar pada pelayanan dan kepuasan stakeholders serta kemampuan untuk mengaktualisasikan management best practice dalam pengelolaan dan pengembangan lembaga pendidikan.

Adapun Konsekuensi logis dari usaha peningkatan mutu pendidikan adalah dibutuhkan kemauan untuk meningkatkan mutu secara maksimal dari setiap komponen sistem pendidikan, mulai dari sumber daya manusia maupun yang berupa material resources. Dalam usaha meningkatkan mutu pendidikan, komponen pendidikan yang berupa sumber daya manusia mempunyai peranan yang sangat penting dalam pencapaian tujuan, visi dan misi yang diinginkan, oleh karena itu, pimpinan lembaga pendidikan berusaha memberikan kepedulian dan perhatian yang serius terhadap pengelolaan sumber daya manusia yang terlibat di dalam lembaga pendidikan tersebut, bukan hanya pendidik dan tenaga kependidikan tetapi juga peserta didik dan orangtua mahasiswa dan masyarakat sebab hanya dengan kesiapan sumber daya manusia yang akan mampu membawa lembaga pendidikan tetap survive dan mampu meningkatkan mutu pendidikan di lembaga pendidikan.

\section{Faktor Yang Mempengaruhi Dalam Peningkatan Mutu.}

Dalam peningkatan mutu sumber daya manusia merupakan suatu konsep yang berupaya melaksanakan sistem manajemen mutu di dunia nasional maupun Internasional, sehingga diperlukan perubahan besar dalam budaya dan sistem suatu organisasi seperti lembaga pendidikan. Ada beberapa faktor yang harus diperhatikan oleh penyelenggara pendidikan di lembaga Islam dapat memenuhi mutu atau kualitas yang baik di antaranya adalah:

a. Perbaikan secara Berkesinambungan

20 Yusri Mansjur, Kelemahan dan Tantangan Dalam Peningkatan Kualitas Mutu Sekolah Pendidikan Dasar, diakses tanggal 10 November 2015. 
Perbaikan secara kesinambungan merupakan unsur paling fundamental dalam dalam meningkatkan kualitas manajemen. Perbaikan berkesinambungan akan berhasil dengan baik bila disertai dengan usaha sumber daya manusia yang tepat, kepercayaan diri, praktis karena faktor manusia merupakan dimensi terpenting dalam perbaikan kualitas dan produktivitas.

b. Pendidikan dan Pelatihan

Pendidikan sebagai suatu proses kegiatan pemberdayaan manusia menjadi SDM yang berkualitas, harus dilandasi oleh sifat dan sikap yang "arif serta bijaksana" 21 , sedangkan Pelatihan berhubungan secara spesifik dengan pekerjaan staf administrasi dan tenaga pendidik sehingga mengetahui apa yang harus dikerjakan dan tata cara aturan yang harus dilakukan sehingga dapat diaplikasikan dengan segera. Dengan demikian, materi pelatihan atau workshop harus bersifat praktis. Pelatihan merupakan bagian dari pendidikan walaupun pendidikan lebih bersifat filosofis dan teoritis, meskipun demikian pendidikan dan pelatihan atau workshop memiliki tujuan yang sama yakni pembelajaran.

c. Kepuasan Klien

Dalam istilah bisnis, klien adalah orang yang membeli dan menggunakan produk perusahaan. Sedangkan di sini adalah siswa, orang tua dan masyarakat atau stake holder. Tujuan bisnis pada hakekatnya adalah untuk menciptakan dan mempertahankan pelanggan. Dalam penerapan Mutu atau kualitas di lembaga pendidikan Islam, kualitas ditentukan oleh pelanggan yaitu siswa, dan lembaga pendidikan juga harus berupaya menciptakan kepuasan siswa. Peran dan tanggung jawab divisi dan manajer harus dilihat dari sudut pandang untuk mencapai kepuasan siswa. Kepuasan siswa dapat memberikan beberapa manfaat : (1) hubungan antara lembaga pendidikan dan para siswa menjadi harmonis; (2) memberikan dasar yang terbaik untuk meningkatkan jumlah siswa untuk masuk ke lembaga pendidikan; (3) dapat mendorong terciptanya loyalitas siswa; (4) reputasi lembaga menjadi baik di mata siswa; dan (5) keuntungan dana yang diperoleh lembaga pendidikan menjadi meningkat.

d. Obsesi terhadap Kualitas

Dalam era globalisasi lembaga pendidikan Islam menghadapi persaingan ketat dengan lembaga pendidikan umum yang ada di seluruh Indonesia. Meningkatnya intensitas dan persaingan menyebabkan setiap lembaga pendidikan harus berusaha meningkatkan kualitas agar kepuasan pelanggan terwujud. Kerangka

\footnotetext{
${ }^{21}$ M. Ihsan Dacholfany, Peranan Pengambilan Keputusan Dalam Rangka menciptakan inovasi Di bidang pendidikan, Jurnal Dewantara Vol I, No .0 1 Januar i-Juni 2016, h.19
} 
dalam kualitas harus didasarkan pada dua alasan pokok, yaitu: (1) orientasi pemasaran, lembaga pendidikan harus dapat memenuhi semaksimal mungkin kebutuhan dan persyaratan yang ditetapkan stakeholder; dan (2) orientasi internal lembaga pendidikan, lembaga pendidikan harus dapat menghindari kerugian, pemborosan. Diupayakan adanya maksimalisasi usaha setiap staf, karyawan, dan guru, penghematan energi sumber daya manusia dan pengidentifikasian peluang penyelesaian masalah.

e. Pendekatan Ilmiah

Melalui manajemen kepemimpinan yang baik, keputusan yang kadang kala bersifat subjektif bisa diminimumkan. Salah satu kuncinya sukses dalam meningkatkan mutu manajemen adalah menggunakan pendekatan ilmiah, dalam pendekatan ilmiah, pengambilan keputusan didasarkan pada data, mencari sumber penyebab dan mengupayakan solusi dalam waktu yang singkat.

f. Komitmen Jangka Panjang

Meningkatkan mutu manajemen merupakan suatu paradigma baru dalam atas berbagai konteks, baik sebagai latar maupun sebagai realitas kekinian serta berbagai kecenderungan atau kemungkinan kondisi masa datang yang diperhitungkan melalui ragam perspektif. Dalam konteks ini, perencanaan tenaga pendidik dan kependidikan merupakan prediksi mutakhir untuk menata kinerja yang lebih dapat merealisasikan program-program pengembangan sumber daya manusia Islami, guna menjawab tuntutan dalam mencerdaskan generasi bangsa menjadi lebih amanah dan bertanggung jawab.

\section{SIMPULAN}

Dalam meningkatkan kualitas sumber daya manusia yang islami, lembaga pendidikan memegang peran yang sangat penting dalam proses peningkatan kualitas sumber daya manusia. Peningkatan kualitas pendidikan merupakan suatu proses yang terintegrasi dengan proses peningkatan kualitas sumber daya manusia itu dengan didukung sarana prasarana, kemauan untuk meningkatkan mutu pendidikan, adanya kompensasi yang sesuai, serta manajemen dan kepemimpinan lembaga pendidikan tersebut. Menyadari pentingnya proses peningkatan kualitas sumber daya manusia, maka pemerintah, pengelola lembaga pendidikan, tenaga pendidik dan kependidikan serta peserta didik berupaya mewujudkan tujuan, visi dan misi tersebut melalui berbagai usaha pembangunan pendidikan yang lebih berkualitas antara lain melalui pengembangan dan perbaikan kurikulum dan sistem evaluasi, perbaikan sarana pendidikan, pengembangan dan pengadaan materi ajar, serta pelatihan bagi guru dan tenaga kependidikan lainnya untuk itu lembaga pendidikan seyogyanya merevitalisasi peran lembaga pendidikan supaya mampu berperan secara optimal dalam mewujudkan manajemen sumber daya manusia (MSDM) dengan 
cara pengembangan, melakukan fungsi manajemen, perencanaan, pengadaan staf sumber daya manusia dengan memberikan penilaian prestasi kerja dan kompensasi serta terpenuhinya sarana prasarana dengan melakukan pelatihan dan pengembangan serta pembinaan hubungan kerja yang efektif untuk kemajuan dan perkembangan lembaga pendidikan, dengan harapan prosedur, pengelolaan baik tenaga pendidik mapun tenaga kependidikan (karyawan) secara efektif dan efisien sesuai dengan tujuan, visi dan misi lembaga pendidikan tersebut.

\section{DAFTAR PUSTAKA}

C.Groenen, Teologi Sakramen Inisiasi Baptisan Krisma: Sejarah dan Sistematika, Jogjakarta: Kanisiu, 1992.

Depnaker, Peningkatan Mutu Terpadu, 1986.

Henrik Bognan, Western Esotericism and Rituals of Initiation,2007.

Mastuki HS. Dkk, Managemen Pondok Pesantren, Jakarta: Diva Pustaka, 2003.

M. F. Gaffar, Membangun Kembali Pendidikan Nasional dengan Fokus: Pembaharuan Manajemen Perguruan Tinggi pada Era Globalisasi, Makalah Konvensi Nasional Pendidikan Indonesia V , Surabaya, 2004.

Martin Amnillah, Implentasi Perencanaan Strategi Pendidikan Dasar Tahun 2001-2003 Dinas Pendidikan Kabupaten Temanggung (Studi Kasus di SLTP Islam Nadirejo), Tesis, (Yogyakarta: PPs. Universitas Negeri Yogyakarta, 2004.

M. Ihsan Dacholfany, Peranan Pengambilan Keputusan Dalam Rangka menciptakan inovasi Di bidang pendidikan, Jurnal Dewantara Vol I, No .01 Januar i-Juni 2016

Syaiful Sagala, Manajemen Strategik dalam Peningkatan Mutu Pendidikan, (Bandung: Alfabeta, 2007.

Tim Penyusun Kamus Pusat Pembinaan dan Pengembangan Bahasa, Kamus Besar Bahasa Indonesia, Jakarta: Balai Pustaka, 1989.

Visi dan Strategi Pembangunan Pendidikan untuk Tahun 2020 Tuntutan Terhadap Kualitas Depdikbud, 1996; Ceramah Menteri Pendidikan dan Kebudayaan pada Konvensi Nasional Pendidikan Indonesia III Ujung Pandang, 4-7 Maret 1996. 